\title{
The Effect of Higher Order Thinking Skill Instruction on EFL Reading Ability
}

Nava Nourdad*, Sanam Masoudi, Parisa Rahimali

University of Tabriz, Iran

Corresponding Author: Nava Nourdad, E-mail: nourdad@tabrizu.ac.ir

\section{ARTICLE INFO}

Article history

Received: October 19, 2017

Accepted: January 09, 2018

Published: May 01, 2018

Volume: 7 Issue: 3

Advance access: March 2018

Conflicts of interest: None

Funding: None

\begin{abstract}
This quantitative and quasi-experimental study dealt with the effect of the teaching higher order thinking (HOT) on the reading comprehension ability of foreign language learners. Since reading ability plays a crucial role in learners' education, it is language teachers' mission to be aware of the useful and beneficial strategies to improve their students' reading comprehension ability. Considering the fruitful results of applying HOT skills in education, the present study was conducted to investigate the effect of their instruction on students' reading comprehension ability. To achieve the objectives of the study, a group of 236 male and female university students majoring in various fields but all taking General English course was selected by convenience sampling. They were randomly assigned into two groups of control and experimental. PET test was applied to homogenize the participants of the two study groups. The study followed pre-test, treatment, post-test design. While the experimental group followed a nine-session treatment on strategies of HOT, the control group was instructed through conventional method determined by the course book. The results of independent samples t-test revealed the positive effect of teaching HOT skills on improving reading comprehension ability of adult EFL learners. Pedagogical implications of these findings for language learners, language teachers, course book developers, and educational policy makers are discussed.
\end{abstract}

Key words: Higher Order Thinking, Reading Comprehension, Bloom's Cognitive Taxonomy, Critical Thinking

\section{INTRODUCTION}

Johnson (1998) believes that, in most educational systems, students only focus on listening lectures, finishing tasks, and responding tests that merely measure the ability to memorize facts, concepts, and theories. This sort of learning has a negative effect on psychological development of students, isolate students, neglect them, and make them feel insecure and exile, eventually leave students without sufficient skills.

Higher order thinking (HOT) skills are significant in teaching and learning. Thinking skills are fundamental in educational process. A learner's thought can affect the ability of learning, speed and effectiveness of learning. Therefore, thinking skills are associated with learning processes. Students who have learned to think represent its positive impact on the development of their education. HOT is the highest level in the hierarchy of cognitive processes. It helps students dominate the challenges of too much information with a limited processing time (Phillips, 2004). HOT arises when someone gets new information, keeps in memory and links it to the existing knowledge and generates this information to achieve a goal or solve a complicated situation. HOT is a major part of creative and critical thinking and creative thinking pedagogy can help students develop more innovative ideas, ideal perspectives and imaginative insights. It can also be noted that HOT emphasizes on developing students' abilities to help them analyze effectively, evaluate by interpreting from existing information and create (synthesize) something new.

According to Grabe (1991), research on reading in a second language and trying to improve target language reading instruction have increased significantly in the first quarter of the last century. Effective reading needs accurate reading skills and trying to perceive automatically (Raymond, 2006).

Reading is a complex process which involves different purposes and varying processes demanding different abilities (Grabe, 1991). Anderson (2006), proposed that the idea of reading comprehension has changed from what has been known as a receptive process to what is now known as an interactive process. Reading comprehension skill separates the "passive" unskilled reader from the "active" readers. It seems that active readers can gain more information from the text and infer the deeper layers of the intended message. Sanders (2001) revealed that in reading comprehension skills the passive unskilled reader is separated from the active reader. In other words, not only do skilled readers read, but they also interact with the text. As an instance, skilled readers can predict, infer and analyze what happens in a story or a piece of reading using clues presented in the text to 
make questions about the main idea or plot of the text. This is very close to the higher order thinking ability. It seems that readers familiar with higher order thinking may comprehend the read texts better. Reading comprehension is the most prevalent skill in foreign language contexts especially when considering academic contexts. To this end the present study aimed at introducing HOT skills to EFL readers and investigating its effect on their text comprehension ability. Accordingly, the following research question guided the investigation:

Does teaching higher order thinking skills improve EFL learners' reading comprehension ability?

\section{REVIEW OF THE RELATED LITERATURE}

Although a relatively recent issue, HOT has been investigated in a few studies. Venville, Adey, Larkin and Robertson (2003) maintained that not only does modern education need recall of information, rote learning of facts and figures or simply performing various learned techniques, but it also requires much more than the mentioned factors. Recently, it is truly obvious that most school curriculums have crucial focus on the development of HOT skills.

According to Tomei (2005), HOT includes the transformation of information and ideas. The mentioned transformation occurs when pupils can combine facts and ideas, synthesize, generalize, and explain hypothesis, and they can also arrive at some conclusion or some interpretation. Students are able to solve the problems, gain understanding and discover novel meanings by manipulating the information and ideas through the aforementioned processes.

McNeil's review (2011) proposed that movement from lower level thinking to higher level thinking is called scaffolding, which is explained in Bloom's Taxonomy and Webb's Depth of knowledge. They described how students should move from lower level thinking to higher level gradually. The mentioned taxonomy was proposed by Benjamin Bloom, an educational psychologist at the University of Chicago, in 1956. Before that time in 1948 , he defined three different significant psychological domains in the learning process as cognitive, affective and psychomotor. The cognitive domain is based on the understanding and knowledge of ideas. The affective domain is dealing with the attitudes, emotions and feelings which are the results of the learning process. The last domain which is called psychomotor is about physical skills. The current study deals with the cognitive domain. Bloom et al. (1956) define six different levels in cognitive domain in Bloom's taxonomy. The mentioned taxonomy is divided in to two parts. The first three levels are called lower order thinking and the second three levels are called higher order thinking.

1. The lowest level of the learning is defined as knowledge. This level is concerned with remembering of previously learned materials.

2. The second level of the taxonomy is called comprehension. In this level the learner goes beyond just memorizing in order to grasp the meaning of the materials.

3. The third level is application. During this level the learner can use the required knowledge in completely novel situations by applying known methods.

4. The fourth level, which is the starting phase of the higher order level, is analysis. In this stage, learners are able to break down the information into component parts that requires calculations and classifications.

5. The fifth level is known as synthesis. During this phase, learners can assemble components together in order to form a new whole such as formulation of a new pattern or creative behavior.

6. The sixth and last level of the Bloom's taxonomy is called evaluation. After all the aforementioned stages, it is time for students to use evaluation in which they can express their ideas by making critical judgments or in other words by judging the value of the information or idea.

Chinedu, Kamin and Olabiyi (2015) reviewed some of the existing practices, thoughts and concepts about HOT, in order to find strategies for improving HOT skills in teaching and learning. This library based work suggests several strategies that teachers can use to improve HOT in their learners, such as the use of concept, inferences, visualization, and schemas.

Another study was performed by Grigatte (2005) who conducted a research to investigate the effect of using HOT strategies on developing child's thinking skills. There were fifty-seven children at the age of six, who took part in the experiment. The researcher's findings showed that pupils who received treatment were more creative and showed high degrees of cognitivism.

Ahiri, Dunifa, Tandklangi, and Ghami (2013) investigated the effect of learning strategies on HOT skills of students with different learning styles. They performed research on the comparisons among higher-order thinking skills of students who were taught by collaborative learning, competitive learning and contextual teaching and learning. Besides they investigated these comparisons among HOT skills of students with auditory, visual and kinaesthetic learning styles. Their findings revealed that applications of contextual, competitive and collaborative learning have different effects on students' HOT skills. That is to say, contextual learning is more effective and useful for kinesthetic students, collaborative learning is more useful to be applied to auditory students and competitive learning is good for visual students. Therefore, the design of the learning-teaching processes should be modelled according to the students learning style preferences.

In another study, Michael and Jones (2015) attempted to investigate the effects of HOT skills and Lower Order Thinking Skills on academic achievement of students in world history class. The researchers had eleven females and eleven males for the study and teacher-made quizzes were used to collect the data. There were both the lower order and higher order instruction based on Bloom's Taxonomy. The results showed that there was a significance difference between the performance of the students taught by higher order methods and lower order methods of instruction. Besides, it definitely revealed that teaching higher order methods was more beneficial and constructive for students. 
In a qualitative study Nourdad (2015) investigated how mediations provided through DA for six types of reading comprehension questions classified according to Bloom et al.'s (1956) cognitive taxonomy affected the readers' development. It was revealed that mediations were more beneficial for higher order questions than the lower order ones and as the cognitive level of the questions raised, mediations led into more development and transcendence of the reading ability.

Lateef, Arshad Dahar, and Latif (2016) investigated the impact of HOT skills of university students on their academic performance. Results depicted that students of undergraduate level can improve their HOT skills, therefore there should be attention to engage students in task-oriented work in order to enhance the HOT skills. Moreover, through internalizing competencies, students can learn many positive characteristics, enhance their thinking, and become more self-disciplined, self-monitored and self-directed thinkers.

Teemant and Hausman (2016) launched a study on the effects of HOT skills on student achievement and proficiency level. The results of the study demonstrated gains in coached teachers' use of HOT and simultaneous gains in their students' language art achievement. It was inferred that, teachers should intentionally engage students in HOT in order to make improvements in their learning level.

Two recent studies investigated Bloom's taxonomy in Iranian educational context. Masoudi (2018) analyzed the content and tasks of newly developed EFL course books for high school students (Vision). Surprisingly she found that the whole books were focusing on lower order skills and only one HOT task was found in one of the books. In the other study Rahimali (2018), compared reflective thinking ability of Iranian EFL students in public schools run by Ministery of Education and private language institutes. Her findings revealed a significantly higher level of reflective thinking in learners developing their English language abilities in institutes. The results of these two studies highlight the critical case of HOT skills in Iranian academic context, especially with regard to foreign language learning.

As reviewed, although many studies have proved the effectiveness of HOT, almost no study, to the best of our smattering knowledge, has investigated the effect of higher order thinking instruction on reading comprehension ability of students. In order to fill this gap and benefiting from the findings in the literature review, the present study aimed at investigating the effect of HOT instruction on reading comprehension the findings of which will be helpful and beneficial for both EFL learners and instructors.

\section{METHOD}

\section{Design}

This quantitative study employed a quasi-experimental design with pre-test, treatment, and post -test format on experimental and control study groups.

\section{Participants}

The participants of the study included 236 male and female students at university of Tabriz majoring in Electrical engi- neering ( $n=45)$, Civil engineering $(n=42)$, Agricultural engineering $(n=45)$, Geography $(n=34)$, Social science $(n=40)$, and Chemical engineering $(n=30)$. The non-random convenience sampling was applied to select the participants from the available general English classes of the researchers. They were all 17 to 27 years old, having Persian as their formal language. Mother tongue of some of participants, however were Turkish or Kurdish.

\section{Instruments}

For the purpose of the homogeneity of the participants in terms of general English language proficiency, PET (Preliminary English Test, 2010) test was applied. This test examines four abilities; each section consists of 25 percent of the total 100 score. The scores of the reading section of the test was used as the reading comprehension pre-test scores. For the post-test, however, reading section of another PET was used as a parallel. The reliability of the pre- and post-tests were calculated through Cronbach's alpha, which were 0.78 and 0.81 respectively. Needless to say that as a standardized test PET bearded the required validity.

\section{Data Gathering Procedures}

The study was carried out according to the following sequential procedures. At the outset, students at various majors were randomly assigned to the intervention and comparison group. PET test was conducted in order to have homogenous participants during the study. The scores of the reading section were used as a measure of pre-treatment reading comprehension ability of the participants. Then came the instruction of the experimental group. The treatment which was instructing HOT skills lasted for nine sessions. The participants were taught three levels of higher order thinking, while the control group followed conventional tasks presented in the course book. Treatment included explanation, presenting examples, doing some group, pair and later individual tasks.

The key of success in HOT instruction is to make the concept clear to the individuals. To this end half of the first treatment session was devoted to clarification of the issue by presenting bloom's cognitive taxonomy and providing examples for each cognitive level, explaining the advantages of HOT and emphasizing that it is a kind of skill which can be improved through practice. The second half of the session was spent explaining class procedures which aimed at creating an intimate and collaborative environment in which learners could freely present their thoughts and ideas, raise questions and seek solutions to the existing problems.

Each session a topic was raised on which groups and whole class discussions were based. The aim of these series of discussions was to teach learners identify the problem, think creatively on it, present their perspectives freely, recommend a solution and criticize the proposed perspectives and solutions. Divergent answers were always welcome, because divergent thinking is the keystone of critical thinking. Motivating learners to present their original ideas on the topic helped them move toward creativity. Individuals were invited to evaluate their own and others' comments. Another 
main feature of the treatment was encouraging the participants to freely raise questions. These questions usually led into further discussions, more critical thinking, and more collaborative class environment. Cooperative learning was emphasized during all treatment sessions.

As the second task of each session participants were asked to choose a topic and use various sources to gather information about it. These topics were massively read on. Each individual had a portfolio to summarize the key points on the topic, identify the main problem, identify and categorize the key concepts and present the personal view over that topic. S/he would relate it to similar issues or the existing background knowledge and point out the common linking point. It is very important to learn connecting concepts to each other.

Since the participants were all adult learners they could be taught to take the responsibility of their own learning process. First they were introduced with the concept of metacognition. Some major metacognitive strategies for planning, monitoring, managing, and assessing were introduced. Later as a subcomponent of metacognition the difference between understanding and memorizing was explained. While understanding is highly emphasized in HOT, memorization is avoided and does not have a role. Learners were encouraged to understand the concepts and try to explain and elaborate them. Sole report of the concept does not do any good in HOT. Trying to explain the acquired concept, individuals have to add their personal portion of understanding to it. It is done through relating new information to prior experience, comparing and contrasting, using analogies and thinking about future application of that concept. All these were practiced in the second treatment session.

The third session was devoted to teaching inference. Being able to get more than explicitly provided information is critical for HOT. Learners were introduced to the issue and were given several everyday life and later academic examples. They were asked to report their personal experience of making inference in their portfolios. The task lasted for two weeks. They were encouraged to present as many samples as possible.

The fourth session was on graphic organizers and concept mapping. The instructor raised the familiar and had been experienced topic of "campus life" and motivated the leaners to discuss its advantages and disadvantages. The discussion lasted for 15 minutes and the instructor presented a tree diagram of the main concepts while the discussion went on. It was followed by a PowerPoint presentation on several other examples and various graphic organizer formats. Later participants were given four texts on various issues to draw a map for the provided concepts and include them in their portfolios.

Problem solving strategies as the inevitable component of HOT were discussed in the fifth session. Identifying the problem is a pre-requisite to solve it. Learners practice knowing the faced problem and stating it in its entirety. Participants were taught that there can be various possible strategies for a single problem. They were flooded by the possible strategies to have a general idea over how to go along solution stages. Later several problems were provided and individuals in groups sought for possible solutions.

The following session cooperative learning was practiced. The instructor tried to carefully plan, structure, monitor, and evaluate for possible interdependence, individual accountability, group processing, face to face interactions, and social skills. This was a difficult job to do because Iranian academic context does not encourage group work, accordingly cooperative learning is not well established among leaners. The teacher explained this drawback and asked the participants to compensate for it and take the advantage of cooperation in their learning.

During the seventh session the relationship between question and answer was explained and practiced. Learners were taught to label the question type and formulate the answer accordingly. Question type directly and greatly influences ways of finding the appropriate solution.

The last two treatment sessions were on the main issue of components of learning process. Learners were encouraged to change their roles as passive recipients of information to active, productive, creative, generators of information. Six components of learning process namely attention, memory, language, graph motor, processing, and organization were talked about, taught and practiced.

Each treatment session lasted for 40 to 50 minutes. After nine sessions of treatment, reading section of another PET test was used as the parallel post-test. The gathered data was later analyzed.

\section{FINDINGS}

At the outset of data collection, a PET test was administered to make sure about the homogeneity of the participants in the two groups. An independent samples t-test was run to compare the language proficiency level of the two study groups. The related descriptive statistics and t-test results are presented in Tables 1 and 2.

As shown in Table 2 there was no significant difference $(\mathrm{t}(234)=.08, \mathrm{p}=94>.05)$ in PET scores of control $(\mathrm{M}=28.09$, $\mathrm{SD}=14.03)$ and experimental $(\mathrm{M}=27.95, \mathrm{SD}=11.91)$ groups, that is, both groups were homogeneous in language proficiency.

Another independent-samples t-test was run to compare the mean scores of the two groups in reading comprehension pre-test, the results of which are presented in Tables 3 and 4.

Table 3 shows that the mean scores of the control group $(\mathrm{M}=11.14, \mathrm{SD}=5.18)$ and the experimental group $(\mathrm{M}=$ $12.00, \mathrm{SD}=4.35)$ were close to each other and the result of the independent samples t-test reflected in Table 4 did not reveal a significant prior difference in the reading ability of the two groups $(\mathrm{t}(234)=-1.37, \mathrm{p}=.17>0.05)$.

Table 1. Descriptive statistics of PET test

\begin{tabular}{lcccc}
\hline Group & N & Mean & $\begin{array}{c}\text { Standard } \\
\text { deviation }\end{array}$ & $\begin{array}{c}\text { Standard } \\
\text { error mean }\end{array}$ \\
\hline PET & & & & \\
Control & 124 & 28.09 & 14.03 & 1.26 \\
Experimental & 112 & 27.95 & 11.91 & 1.13 \\
\hline
\end{tabular}


An independent-samples t-test was conducted to compare the scores of control and experimental groups in post-test regarding their reading comprehension ability. Tables 5 and 6 present data on post-treatment reading comprehension test.

Tables 5 and 6 reflect a significant difference $(\mathrm{t}(234)=$ $2.52, \mathrm{p}=.01<.05)$ in post-treatment scores of reading comprehension test in control $(\mathrm{M}=1.29, \mathrm{SD}=5.49)$ and experimental $(\mathrm{M}=13.90, \mathrm{SD}=4.18)$ groups, that is, as a result of the treatment the experimental group outperformed the control group and teaching HOT skills was as an efficient means of improving the students' reading comprehension ability. In other words, such results support the view which perceives the use of the HOT strategies as a good classroom strategy that helps students develop important language skills which will help them improve their ability in reading comprehension.
This finding confirms the claims of Larson and Miller (2011) according to which most students are working on the lowest levels of thinking and teachers should prepare students with $21^{\text {st }}$ century skills. They emphasize that teachers should encourage students to apply knowledge, analyze that knowledge in multiple ways, synthesize or create new knowledge, and continuously evaluate it. For these researchers progressing through Bloom's Taxonomy meets the requirements of $21^{\text {st }}$ century skills. In this line, Jerald (2009) asserts that the changing world forces students to apply their in-class-acquired knowledge to deal with the real world challenges to success in the $21^{\text {st }}$ century. Also The Partnership for $21^{\text {st }}$ Century Skills (2007) highlights the need for higher-level thinking to meet the $21^{\text {st }}$ century skills.

Table 2. Independent samples t-test on PET scores of study groups

\begin{tabular}{|c|c|c|c|c|c|c|c|c|c|}
\hline & \multicolumn{2}{|c|}{$\begin{array}{c}\text { Levene's test } \\
\text { for equality of } \\
\text { variances }\end{array}$} & \multicolumn{7}{|c|}{ t-test for equality of means } \\
\hline & \multirow[t]{2}{*}{$\mathbf{F}$} & \multirow[t]{2}{*}{ Sig. } & \multirow[t]{2}{*}{$\mathbf{t}$} & \multirow[t]{2}{*}{ df } & \multirow[t]{2}{*}{ Sig. (2-tailed) } & \multirow[t]{2}{*}{$\begin{array}{c}\text { Mean } \\
\text { difference }\end{array}$} & \multirow[t]{2}{*}{$\begin{array}{l}\text { Standard error } \\
\text { difference }\end{array}$} & \multicolumn{2}{|c|}{$\begin{array}{l}\text { 95\% confidence } \\
\text { interval of the } \\
\text { difference }\end{array}$} \\
\hline & & & & & & & & Lower & Upper \\
\hline \multicolumn{10}{|l|}{ PET } \\
\hline $\begin{array}{l}\text { Equal variances } \\
\text { assumed }\end{array}$ & 2.550 & 0.11 & 0.08 & 234 & 0.94 & 0.13 & 1.70 & -3.22 & 3.49 \\
\hline $\begin{array}{l}\text { Equal variances } \\
\text { not assumed }\end{array}$ & & & 0.08 & 233.12 & 0.94 & 0.13 & 1.69 & -3.20 & 3.46 \\
\hline
\end{tabular}

Table 3. Descriptive statistics of Pre-test

\begin{tabular}{llcccr}
\hline & Group & N & Mean & Standard deviation & Standard error mean \\
\hline \multirow{2}{*}{ Pre-test } & Control & 124 & 11.14 & 5.18 & 0.46 \\
& Experimental & 112 & 12.00 & 4.35 & 0.41 \\
\hline
\end{tabular}

Table 4. Independent samples t-test on pre-test scores of study groups

\begin{tabular}{|c|c|c|c|c|c|c|c|c|c|}
\hline & \multicolumn{2}{|c|}{$\begin{array}{l}\text { Levene's test } \\
\text { for equality of } \\
\text { variances }\end{array}$} & \multicolumn{7}{|c|}{ t-test for equality of means } \\
\hline & \multirow[t]{2}{*}{$\mathbf{F}$} & \multirow[t]{2}{*}{ Sig. } & \multirow[t]{2}{*}{$\mathbf{t}$} & \multirow[t]{2}{*}{ df } & \multirow[t]{2}{*}{ Sig. (2-tailed) } & \multirow[t]{2}{*}{$\begin{array}{c}\text { Mean } \\
\text { difference }\end{array}$} & \multirow[t]{2}{*}{$\begin{array}{l}\text { Standard error } \\
\text { difference }\end{array}$} & \multicolumn{2}{|c|}{$\begin{array}{l}95 \% \text { confidence } \\
\text { interval of the } \\
\text { difference }\end{array}$} \\
\hline & & & & & & & & Lower & Upper \\
\hline \multicolumn{10}{|l|}{ Pre-test } \\
\hline $\begin{array}{l}\text { Equal variances } \\
\text { assumed }\end{array}$ & 4.15 & 0.043 & -1.37 & 234 & 0.17 & -0.85 & 0.63 & -2.09 & 0.38 \\
\hline $\begin{array}{l}\text { Equal variances } \\
\text { not assumed }\end{array}$ & & & -1.38 & 232.79 & 0.17 & -0.85 & 0.62 & -2.08 & 0.37 \\
\hline
\end{tabular}

Table 5. Descriptive statistics of Post-test

\begin{tabular}{llcccr}
\hline & Group & N & Mean & Standard deviation & Standard error mean \\
\hline Post-test & Control & 124 & 12.29 & 5.49 & 0.49 \\
& Experimental & 112 & 13.90 & 4.18 & 0.39 \\
\hline
\end{tabular}


Table 6. Independent samples t-test on post-test scores of study groups

\begin{tabular}{|c|c|c|c|c|c|c|c|c|c|}
\hline & \multicolumn{2}{|c|}{$\begin{array}{l}\text { Levene's test } \\
\text { for equality of } \\
\text { variances }\end{array}$} & \multicolumn{7}{|c|}{ t-test for equality of means } \\
\hline & \multirow[t]{2}{*}{$\mathbf{F}$} & \multirow[t]{2}{*}{ Sig. } & \multirow[t]{2}{*}{$\mathbf{t}$} & \multirow[t]{2}{*}{ df } & \multirow[t]{2}{*}{ (Sig. 2-tailed) } & \multirow[t]{2}{*}{$\begin{array}{c}\text { Mean } \\
\text { difference }\end{array}$} & \multirow[t]{2}{*}{$\begin{array}{l}\text { Standard error } \\
\text { difference }\end{array}$} & \multicolumn{2}{|c|}{$\begin{array}{l}95 \% \text { confidence } \\
\text { interval of the } \\
\text { difference }\end{array}$} \\
\hline & & & & & & & & Lower & Upper \\
\hline \multicolumn{10}{|l|}{ Post-test } \\
\hline $\begin{array}{l}\text { Equal variances } \\
\text { assumed }\end{array}$ & 0.103 & 0.005 & 2.52 & 234 & 0.01 & -1.61 & 0.64 & -2.87 & -0.35 \\
\hline $\begin{array}{l}\text { Equal variances } \\
\text { not assumed }\end{array}$ & & & 2.55 & 227.58 & 0.01 & -1.61 & 0.63 & -2.86 & -0.37 \\
\hline
\end{tabular}

Considering the great limitations of Iranian EFL learners in thinking skills on one hand, and the importance of higher-order thinking skills for educational and real life success of the individuals on the other hand, this study has the following recommendations for language programs and teachers:

Language teachers should aim at increasing the level of thinking in their classes. This can best be achieved through explicit instruction of higher-order thinking skills. Language teachers should also raise higher level questions in their classes to invite the participants to think in higher levels. Also the tasks provided for the learners should make them analyze, evaluate and create new pieces of knowledge based on the acquired, comprehended and synthesized knowledge.

Assessment can to be helpful for teachers in achieving their intended outcomes through positive washback. So including higher-order thinking skills on assessments and having test items that encourage the learners to focus on higher layers of Bloom's taxonomy may raise the awareness and motivation of the learners to focus on them during the instruction.

All in all, language teachers can play a great role in increasing the cognition and thinking level of Iranian EFL learners, but there are other sides of this issue as well. The language curriculum is not prepared by language teachers, and in most cases even the syllabus is not teacher-developed. Therefore, curriculum developers and syllabus designers should pave the way for language teachers and learners to present higher levels of thinking in language classes and later transfer it to real life. Considering the scope of the paper, all the mentioned issues were on foreign language learning. However, for Iranian students, education starts years before starting foreign language learning. Educational system of Iran, therefore, should pay much more attention on developing the thinking ability of these individuals. Some students might not be successful in their academic lives, some might never master a foreign language, but the important point is to guide them to be successful in their lives through teaching them how to think!

\section{CONCLUSION}

This study aimed at finding a solution for deficiencies in Iranian EFL learners' reading comprehension skill. Be- sides, this project provides a good example of continuous professional development to help the instructors and learners' achievement by the means of emphasizing on higher-order thinking skills in their syllabuses. The results of this study indicated that the use of the HO strategies as regular classroom strategies will be beneficial and advantageous for the learners, because the results did prove significantly positive effects on learners reading skill. According to the results the instruction of higher order thinking skills helped EFL learners improve their reading comprehension ability. This study can help in the effort of forming a better understanding of the using and instructing HOT skills in Iranian educational systems and specially can help to improve EFL learner's reading comprehension skills in which learners face serious difficulties. Finally, it is obviously known that the findings of this research can positively impact instructional and curricular decisions at all levels.

\section{REFERENCES}

Ahiri, J., Dunifa, L., Tanduklangi, A., \& Ghani, A. (2013). The effect of learning strategies on Higher-Order Thinking skills students with different learning styles. International Journal of Science and Research, 4(9), 12041211.

Anderson, N.J. (2006). Crossing borders through reading. Selected papers from the fifth International symposium on English Teaching. Taipei, Crane.

Bloom, B. S. (1956). Taxonomy of educational objectives: The classification of educational goals. New York: David MC Kay Company, Inc.

Chinedu, C., Olabiyi, O., \& Kamin, Y. (2015). Strategies for improving higher order thinking skills in teaching and learning of design and technology education. Journal of technical education and training, 7(2), 35-43.

Grabe, W. (1991). Current development in second language reading research. TESOL Quarterly, 25(2), 375-406.

Grigaite, D. (2005). Developing Child's thinking Skills by semantic Mapping Strategies. CEEOL Trames: Teaduste Akadeemia Kirjastus.

Jerald, C.D. (2009). Defining a $21^{\text {st }}$ Century Education. Center for Public Education. 
Retrieved in December, 2017 from http://www.centerforpubliceducation.org/Learn-About/2 $1^{\text {st }}$-Century/Defining-a-2 $1^{\text {st }}$-Century-Education-Full-Report-PDF.pdf

Larson, L.C., \& Miller. T.N. (2011). $21^{\text {st }}$ century skills: Prepare students for the future. Kappa Delta Pi Record, 47(3), 121-123.

Lateef, A., Dahar, M.A., \& Latif, Kh. (2016). Impact of higher order thinking skills of university students on their academic performance. Pakistan Association of Anthropology, 28(2), 2031-2035.

Masoudi, S. (2018). A content-based analysis of the activities in Iranian senior high school textbook. Unpublished M.A. thesis. University of Tabriz. Tabriz: Iran.

McNeil, R. C. (2011). A program evaluation model: using Bloom's taxonomy to identify outcome indicators in outcomes- based program evaluations. Journal of adult education, 40(2), 24-29.

Nourdad, N. (2015). Responses to mediation for six levels of reading comprehension questions based on bloom's taxonomy. The Iranian EFL journal, 11(3), 94-111.

Phillips, J.A. (2004). Keberkesanan pengajaran kemahiran berfikir: perubahan kepada system persekolahan. Paper presented at the Seminar Kebangsaan Pengajaran Kemahiran Berfikir: Tinjauan Kejayaan Satu Dekad.
Rahimali, P. (2018). Comparing reflective thinking ability of EFL learners in language institutes and schools. Unpublished M.A. thesis. University of Tabriz. Tabriz: Iran.

Raymond, C.J. (2006). Strategies for Teaching Reading Comprehension. Received at March 2017 from http:// www.readingquest.org/strat/graphic.html.

Sanders, M. (2001). Understanding Dyslexia and Reading Process: A Guide for Educators and Parents. Needham Heights 'MA: Allyn and Bacon.

Teemant, A., \& Hausman, C. S. (2016). Quasi-experimental evidence of critical sociocultural pedagogy. Manuscript in preparation.

The Partnership for $21^{\text {st }}$ Century Skills (2007). $21^{\text {st }}$ century curriculum and instruction. Retrieved in July 2017, from http://www.p21.org/news-events/press-releases/360-partnership-for-2 $1^{\text {st }}$-century-skills-releases-updated-framework-for- $21^{\text {st }}$-century-learning.

Tomei, Laurence. (2005). Taxonomy for the technology Domain. Hershey, PA: Information Science Publishing.

Venville, G., Adey, P., Larkin, S., \& Robertson, A. (2003). Fostering thinking through science in the early years of schooling. International journal of science education, 25(11), 1313-1331. 